\title{
Kerk en Samelewing 25 jaar later: Was die kool die sous werd?
}

\begin{abstract}
Church and Society 25 years later: Was ith worth the while?

25 Years have passed since the General Synod of the Dutch Reformed Church accepted a new policy document: Church and Society in Light of Scripture. This document came into being after a several years of struggle. The reaction to the document led to a schism in the church and the founding of the Afrikaanse Protestantse Kerk. This article asks the question if the trouble Church and Society caused in the church was worth the while and then comes to the conclusion that it definitely was. Looking back after 25 years, Church and Society helped the Dutch Reformed church to get rid of the burden of apartheid and opened new doors on the church's way to the challenges of the new millennium.
\end{abstract}

\section{INLEIDING}

Die beleidsdokument Kerk en Samelewing is in Oktober 1986, 25 jaar gelede, deur die Algemene Sinode van die Ned Geref. Kerk aanvaar. Die aanvaarding van hierdie dokument het tot grootskaalse reaksie in die kerk, en uiteindelik tot die ontstaan van die Afrikaanse Protestantse Kerk in 1987, gelei. 25 Jaar later kan die vraag met reg gevra word: "Was die kool die sous werd?" Was die koersverandering waarvoor die Ned Geref. Kerk gekies het, regtig van soveel waarde? Ten einde op hierdie vraag te antwoord, sal daar in hierdie artikel oorsigtelik na die aanloop tot, en die aanvaarding van Kerk en Samelewing in 1986, gekyk word. Die reaksie op die dokument sal onder oë geneem word voordat daar tenslotte stil gestaan sal word by enkele deure wat vir die kerk oopgegaan het om daarmee aan te toon dat die kool inderdaad die sous werd was.

\section{DIE AANLOOP TOT KERK EN SAMELEWING}

Die amptelike aanloop tot Kerk en Samelewing begin by die besluit van die Algemene Sinode van die Ned Geref. Kerk van 1982 om Ras Volk en Nasie ${ }^{1}$ te hersien. Die besluit, wat op 14 Oktober 1982 geneem is, het soos volg gelui:" 1.1 Die Algemene Sinode bly homself gelyk en besluit dat Ras, Volk en Nasie indringend in die lig van die Skrif hersien word vir oorweging deur die volgende Algemene Sinode" (Handelinge 1982:1182). Die Sinode het dit verder besluit om 'n Studiekommissie saam te roep wat die "beleid van die Ned Geref. Kerk" "korter en duideliker" en in'n eenvoudiger en makliker vorm moes stel. Naas die prinsipiële gedeelte moes die verslag ook die "praktiese implikasies" wat dit vir die kerk inhou duidelik uitspel (Handelinge 1982:1380).

\subsection{Ekumeniese afkeur}

Die aanloop tot hierdie besluit begin egter heelwat vroeër. Tydens die Algemene Sinode van

1 Ras, Volk en Nasie en volkereverhoudinge in die lig van die Skrif is deur die Algemene Sinode van 1974 aanvaar as amptelike beleidsdokument wat die Ned Geref. Kerk se standpunt oor verhoudinge tussen verskillende rasse weergee. 
1978 het die Breë Moderatuur in sy verslag aan die sinode gemeld dat die "rapport van 1974 redaksioneel verwerk is" en in Nederlands, Engels en Duits vertaal is (Handelinge 1978:30). Die bedoeling was duidelik om die beleid van die Ned Geref. Kerk aan die buite wêreld bekend te stel. Dr FE O' Brian Geldenhuys, Direkteur van Ekumeniese Sake is na Europa gestuur om die verslag te oorhandig aan die "top beheerliggame van die Protestante kerke in Engeland, Nederland, Duitsland en Switserland" (Geldenhuys 1982:81). Negatiewe reaksie op die dokument was vir die Ned Geref. Kerk 'n duidelike aanwyser dat die beleid dringend hersien moes word. Die Gereformeerde Kerke in Nederland het duidelike en ernstige kritiek uitgespreek teen die regverdiging van die politieke bestel van apartheid wat in Suid Afrika aan die orde was (Handelinge 1978:48). Die Switserse Federasie van Protestantse kerke het in 1978'n besoek aan Suid Afrika gebring en terselfdertyd ' $n$ verslag: Theology - Advocate or Critic of Apartheid? A critical Study of the Landman Rapport (1974) of the Dutch Reformed Church (SA) aan die Ned Geref. Kerk oorhandig (Agenda 1979:23). Ernstige kritiek is in die verslag teen Ras, Volk en Nasie uitgespreek (Van der Merwe 1990:90). Die Reformierte Bund van Duitsland het hulle op 22 September 1979 aangesluit by die koor van kritiek (Handelinge 1982:158). Dat die Ned Geref. Kerk met Ras, Volk en Nasie nie bereik het wat hy hom ten doel gestel het nie, word bevestig deur verslag van die afvaardiging van die Ned Geref. Kerk na verskillende oorsese konsultasies in 1979. In hierdie verslag word aanbeveel dat Ras, Volk en Nasie grondig hersien moes word (Van der Merwe 1990:201).

\subsection{Die Hervormingsdaggetuienis}

Dit is egter nie net kritiek uit die buiteland wat' $n$ groot rol gespeel het in die besluit om Ras Volk en Nasie te hersien nie. Belangrike impulse het ook in Suid Afrika op die kerk ingewerk. Op 5 November 1980 is 'n getuienis van agt teoloë ${ }^{2}$ in Die Kerkbode gepubliseer (Die Kerkbode 1980:605). Die getuienis het gou bekend geword as die Hervormingsdaggetuienis en het'n groot storm in die Ned Geref. Kerk laat losbars (Van der Merwe 1990:281). Hierdie storm het egter gehelp om gesprek te stimuleer en om die kritiek teen Ras, Volk en Nasie op die agenda van die kerk te hou.

Die Getuienis het aan die volgende sake aandag gegee:

- die skynbare onvermoë van die geïnstitusionaliseerde kerk om sy Godgegewe roeping van versoening te vervul,

- die plig van die kerk om sy lidmate en die staat van profetiese leiding te voorsien,

- die uitskakeling van verdeeldheid en polarisasie en die oproep tot kerkeenheid,

- Die uitskakeling van alle vorme van rassisme en betoning van solidariteit met almal wat onder die huidige politieke bestel ly,

- Die onvoorwaardelike aanvaarding van mekaar deur alle bevolkingsgroepe.

Dit is duidelik dat die inhoud van die Getuienis grootliks ooreen gestem het met die kritiek wat uit die buiteland teen Ras, Volk en Nasie geopper is. Hofmeyr is korrek wanneer hy skryf dat die Getuienis nie maar as net nog 'n verklaring afgemaak kon word nie, maar dat dit as 'n waterskeiding aan die begin van die tagtigerjare beskou moes word (Die Kerkbode 1981:8).

\subsection{Die Ope Brief}

Die impak van die Getuienis is verder versterk met die publikasie van die Ope Brief op Junie 1982. Die brief wat deur 123 predikante en lidmate onderteken is, het op 9 Junie 1982 in Die Kerkbode verskyn (Die Kerkbode 9 Junie 1982:1). Volgens die opstellers van die Ope Brief het verskeie faktore'n rol gespeel in die opstel van die brief. Die debat wat deur die Hervormingsdaggetuienis

2 Die ondertekenaars van die Hervormingsdaggetuienis was CFA Borchardt, HJB Combrinck, BA Müller, WP Esterhuyse, JA Heyns, WD Jonker, HW Rossouw en AB du Toit. 
ontketen is, die publikasie van die boek: Stormkompas ${ }^{3}$ en 'n teologiese kongres wat vanaf 18 21 Januarie 1981 aan die Universiteit van Pretoria gehou is, het 'n groot bydrae gelewer om 'n atmosfeer te skep wat'n groot invloed uitgeoefen het op die brief. Dit "was vir hulle sonder meer duidelik dat die brief direk aansluit by die kritiese vrae van die sewentigerjare" (Bosch ea. 1982:25). Prof DJ Bosch het die doel van die Ope Brief verder as volg verwoord: “Dit is'n oproep aan die kerk, in die naam van die Koning van die Kerk om, op bepaalde punte, die kloof tussen die teologiese en sosiologiese gestaltes van die kerk te verklein" en verder "Die Ope Brief is dus nie 'n poging om oor elke aspek van die kerklike lewe standpunt in te neem nie. Dit gaan slegs oor sekere aspekte van kerk-wees wat in die oordeel van die ondertekenaars in hierdie bepaalde tydsgewrig dringend aandag moet kry (Bosch ea. 1982:53). Die Ope Brief het ondermeer versoening, die eenheid van die kerk en die profetiese roeping van die kerk aangespreek terwyl daar ook solidariteit betuig is met diegene wat gely het onder maatskaplike wantoestande 4 .

Prof JA Heyns het die belangrikheid van die Ope Brief onderstreep toe hy kort na die publikasie daarvan in die Kerkbode geskryf het dat die Ope Brief 'n "noodkreet om gespreksgeleentheid" was. Hy het voortgegaan deur te sê: "Ek hoor stemme wat roep om helderheid en duidelikheid te midde van groot onsekerheid en verwarring" (Die Kerkbode 23 Junie 1982: 5). Heyns het ook die vraag gevra of die kerk nog met Ras, Volk en Nasie kon volstaan en of daar dinge was wat op 'n nuwe manier gesê moes word: "Vra nuwe tye nie ook vir nuwe antwoorde nie? Het ons bygebly of het ons die proses van voortdurende reformasie êrens laat stol?" (Die Kerkbode 23 Junie 1982:5).

Die geskiedenis het intussen bewys dat Heyns se oordeel oor die belang van die Ope Brief korrek was. Dit was ongetwyfeld een van die groot stimuli wat op die kerk ingewerk het oppad na Kerk en Samelewing.

\subsection{Die vergadering van die Wêreldbond van Gereformeerde Kerke: Ottawa 1982}

'n Verdere gebeurtenis wat 'n groot invloed op die besluit van 1982 uitgeoefen het, was die vergadering van die Wêreldbond van Gereformeerde kerke wat vanaf 17-27 Augustus 1982 in Ottawa, Kanada plaasgevind het (Proceedings 1982:1). Tydens hierdie byeenkoms is die finale spyker in die isolasie kis van die Ned Geref. Kerk geslaan. Dit was vroeg reeds duidelik dat die Ned Geref. Kerk met sy ondersteuning van apartheid in die spervuur sou wees toe afgevaardigdes van die Ned Geref. Sending Kerk en van die Reformed Chuch in Africa uit die Nagmaalsdiens aan die begin van die byeenkoms, gestap het (Die Kerkbode 25 Augustus 1982:3). Die Nagmaalsboikot is opgevolg met'n referaat deur dr AA Boesak met die titel: "God made us all but ... Racism and the World Alliance of Reformed Churches" (Boesak 1984:108). In die referaat het Boesak beklemtoon dat die WBGK duidelik standpunt teen rassisme moes inneem. Hy het voortgegaan om die Ned Geref. Kerk uit te sonder as die groot sondebok: "the white Dutch Reformed Churches must assume special responsibility for the situation" en verder "For the struggle in South Africa is not merely against an evil ideology; it is against a pseudo religious ideology that was born in and continues to be justified out of the bosom of the Reformed churches." (Boesak 1984:110). Tydens die bespreking van die verslag: Racism and South Africa het dit duidelik geword dat die Ned Geref Kerk uit die liggaam geskors sou word. Die skorsing het op 27 Augustus 1982 'n voldonge feit geword toe die vergadering met 'n groot meerderheid ten gunste daarvan besluit

3 Die boek het in 1981 onder die redakteurskap van Prof NJ Smit en drs. FE o' Brein Geldenhuys en PJG Meiring verskyn. Dit het 'n grootskaalse storm ontketen as gevolg van die 44 stellings wat daarin gemaak is.

4 In die Ope Brief is spesifiek verwys na gedwonge verskuiwing van mense, die ontwrigting van trekarbeid op gesinne, onderbesteding aan swart onderwys en onvoldoende en swak behuising vir swart mense (Bosch 1982:13-17). 
het (Proceedings 1982:110). Ds. GSJ Moller, redakteur van Die Kerkbode, het die invloed van die gebeure te Ottawa reg opgesom deur te skryf dat die Ned Geref. Kerk hier voor'n ernstige ultimatum te staan gekom het. Hy het verder geskryf dat die kerk se reaksie voorts "belangrik sou wees vir die bevordering of stremming van die belange van die koninkryk van Christus in Suid Afrika (Die Burger 27 Augustus 1982:19). Afgevaardigdes na die Ottawa vergadering het hierdie standpunte gedeel. Prof JA Heyns het in 'n TV onderhoud gesê dat dit veral die gaping tussen beleid en praktyk was, wat aandag verdien het. Ds. JE Potgieter het ook die nodigheid van selfondersoek beklemtoon (Die Kerkbode 1 September 1982:1). Prof WD Jonker het die gevoel in die kerk die raakste opgesom deur te sê: "Vir ons is dit egter nou belangrik om onsself van elke vorm van rassisme te distansieer, nie omdat Ottawa dit vra nie, maar omdat rassisme eenvoudig sonde is" (Die Kerkbode 1 September 1982:1).

Die Ned Geref. Kerk was duidelik by'n kruispad. Die negatiewe kritiek wat Ras, Volk en Nasie ontlok het, het duidelik aan die kerk getoon dat sy beleid nie die toets deurstaan het nie (Van der Merwe 1990:439). Dit het die Algemene Sinode van 1982 eintlik geen ander keuse gelaat as om te besluit om Ras, Volk en Nasie te hersien nie. ${ }^{5}$ Dit sou vier jaar neem en uitloop op die verslag: Kerk en Samelewing -'n Getuienis van die Ned Geref. Kerk (Van der Merwe 1990:464).

\section{DIE VERSLAG TER TAFEL}

Die verslag van die Hersieningskommissie het op 20 -22 Oktober 1986 in Kaapstad ${ }^{6}$ voor die Algemene Sinode van die Ned Geref. Kerk gedien. Weens die vertroulikheid daarvan is dit nie by die Agenda ingebind nie, maar is slegs 2500 eksemplare daarvan gedruk en afsonderlik aan die afgevaardigdes gestuur (Van der Merwe 1990:465).

Die verslag is paragraaf vir paragraaf aan die orde gestel en die bespreking daarvan het twee volle dae geduur (Handelinge 1986:649). Tydens hierdie twee dae het die sinode vier ingrypende besluite geneem wat die kerk onherroeplik op 'n nuwe koers sou plaas. Dit het gehandel oor oop kerkdeure, oop lidmaatskap, apartheid en rasgemengde huwelike en was 'n duidelike wegbeweeg van vroeëre standpunt van afsonderlikheid.

Paragraaf 270 het soos volg gelui: "Die lidmaatskap van die Ned Geref. Kerk is oop" (Kerk en Samelewing 1986:46). Hierdie besluit het dit moontlik gemaak vir lidmate van ander rasse om lidmaat van Ned Geref. Kerk gemeentes te word. In paragraaf 273 is dit duidelik gestel dat die kerk ' $n$ "evangelieverkondigende gemeenskap" is. Dit het beteken dat lidmate en ampsdraers elke geleentheid moes aangryp om die woord van God aan mense te verkondig. Hieruit het gevolg dat: "eredienste en ander byeenkomste toegangklik is vir alle besoekers wat begeer om in gemeenskap met ander gelowiges na die woord te luister" (Kerk en Samelewing 1986:47). Met hierdie besluit is die kerk se deure prakties vir mense van alle rasse oopgestel. In paragraaf 305 het die sinode verklaar dat die Skriftuurlike begronding van die beleid wat bekend geword het as apartheid nie as voorskrif uit die Bybel afgelees kon word nie. "Die poging om so ' $n$ voorskrif uit die Bybel te regverdig, moet as fout erken en afgewys word" (Kerk en Samelewing 1986:52). Alhoewel die sinode nie die volle tree gegee het om apartheid as sonde te bely nie, was dit 'n eerste stap om te erken dat die Bybelse begronding van die Nasionale Party se beleid van apartheid verkeerd was. Die laaste van die ingrypende besluite was die oor rasgemengde huwelike. Die sinode het besluit: "Die Skrif verbied nie rasgemengde huwelike nie" (Kerk en Samelewing 1986:61). Dit was'n radikale breuk met die standpunt van Ras, Volk en Nasie wat uitdruklik verklaar het dat rasgemengde huwelike ongewens en ongeoorloof was

5 Die besluit is op 14 Oktober 1982 geneem. Vgl. punt 2 van hierdie artikel

6 Die sewende vergadering van die Algemene Sinode van die Ned Geref. Kerk het vanaf 14 Oktober 1986 in Kaapstad vergader. 
(Ras Volk en Nasie 1974:100). Die besluit is egter gekwalifiseer deur te verklaar: "Die Kerk moet egter in sy pastorale arbeid daarteen waarsku dat maatskaplike omstandighede, lewens- en wêreldbeskoulike, kulturele, sosio-ekonomiese en ander dergelike verskille en faktore ernstige spanning kan veroorsaak (Kerk en Samelewing 1986:61).

\section{REAKSIE OP KERK EN SAMELEWING: 'N GROOTSKAALSE STORM}

Hierdie besluite van die sinode het hewige reaksie uitgelok en die Ned Geref. Kerk in die grootste storm van sy geskiedenis gedompel. Dr JJ Gerber is korrek wanneer hy meen dat die reaksie in vier groepe verdeel kan word. Eerstens was daar' $n$ stille meerderheid wat dit verslag bloot aanvaar het". Tweedens was daar'n groep wat van mening was dat dit "too little too late was". 8 'n Derde groep het gejuig oor die besluit wat geneem is terwyl'n laaste groep gesê het: "Ons is verraai" (Gerber : Teologiese dag Universiteit van Pretoria 9 Februarie 2011).

Dit was veral die media wat ' $\mathrm{n}$ groot rol in die reaksie gespeel het. Met opskrifte soos: "Eredienste oop vir almal" (Die Burger 22 Oktober 1986:1); "NG Kerk bely! - Apartheid was dwaling" (Die Vaderland 20 Oktober 1986:1) en "Sinode lê grondslag vir breuk met Afrikaner" (Die Afrikaner 29 Oktober 1986:4) is die nuus oor Kerk en Samelewing die wêreld ingestuur. Dit het die tafel gedek vir'n protesaksie deur lidmate wat sou uitloop op 'n kerkskeuring en die stigting van die Afrikaanse Protestantse Kerk.

Die grondwerk vir hierdie protesaksie is reeds in September 1983 tydens die sogenaamde Silverton-byeenkoms gedoen (Van der Merwe 1990:617). Alhoewel prof CWH Boshoff protes teen die voorgestelde nuwe grondwet as die rede vir die byeenkoms voorgehou het, was dit duidelik dat hierdie groep krampagtig aan eiesoortigheid en differensiasie wou vasklou. Hulle was voorstanders van die beleid van "afsonderlike ontwikkeling" wat deur die Ned Geref. Kerk teologies ondersteun is en deur Ras, Volk en Nasie bevestig is. Lede van hierdie groep het 'n leidende rol gespeel in die amptelike protesaksie wat op dreef sou kom $^{9}$ (Van der Merwe 1990:621).

Die eerste duidelike teken dat'n groot protesaksie aan die kom was, was'n byeenkoms van 'n "paar honderd" Ned Geref. lidmate wat uit alle dele van die land op 2 November in Verwoerdburg (nou: Centurion) saamgetrek het (The Citizen 3 November 1986:5). Tydens hierdie byeenkoms is besluit om 'n massavergadering te reël op 28 November 1986 en om 'n Voortsettingskomitee ${ }^{10}$ aan te wys wat terselfdertyd as studiekomitee moes dien (Die Burger 3 November 1986:2). Die komitee het opdrag ontvang om die besware teen die besluite van die sinode te formuleer en te motiveer. Die aanbevelings van die komitee sou op'n massabyeenkoms wat op 28 November in die Skilpadsaal in Pretoria sou plaasvind, bespreek word en aanbevelings oor gekoördineerde optrede sou daar geneem word (Die Burger 3 November 1986:5).

Namate die nuus oor die protesvergadering versprei het, het die omvang van die storm waarin die kerk homself bevind het, duidelik geword. Die toedrag van sake het daartoe gelei dat

7 Die feit dat al die streeksinodes van die Ned Geref. Kerk Kerk en Samelewing tydens die sinodesittings van 1987 met'n groot meerderheid aanvaar het, ondersteun hierdie standpunt Vgl. Die Kerkbode 23 September 1987:1 en Kerkbode 28 Oktober 1987:1

8 John de Gruchy is 'n voorbeeld van hierdie standpunt. Hy skryf: "But at its General synod in 1986 the NGK finally, if timidly, gave up the attempt to provide biblical and theological justification for its report on Church and Society." En verder: "History has unfolded in such a way, however, that the new position of the NGK was totally inadequate, in fact, it was nothing more than a theological rationalization of the governments own attempt to reform apartheid (De Gruchy 2004:195).

9Ds. MC Adendorf, ds. Mossie van den Berg en ds. Andrew Gerber het 'n leidende rol gespeel.

10 Die komitee het bestaan uit prof WJG Lubbe, prof Alkmaar Swart, As G Cruywagen, ds. E Friis, dr JC Kruger, ds. CC Colyn, ME M Roos, prof M Verster en prof S Jacobs. 
prof JA Heyns'n oproep tot kalmte gemaak het en 'n beroep op lidmate gedoen het om niks te doen voordat hulle die publikasie Kerk en Samelewing volledig bestudeer het nie (Die Vaderland 11 November 1986:4).

In'n poging om gemoedere te kalmeer, het'n informele gesprek op 26 November 1986 tussen die Dagbestuur van die Algemene Sinodale Kommissie van die Ned Geref. Kerk en die Studie -kommissie van die beswaarde lidmate in Pretoria plaasgevind ${ }^{11}$ (Beeld 27 November 1986:6). Hierdie gesprek kon egter nie verhoed dat die protesvergadering van beswaarde lidmate op Vrydag 28 November 1986 in die Skilpadsaal voortgaan nie (Rapport 30 November 1986:1).

Tydens die vergadering, wat deur 2500 beswaarde lidmate bygewoon is, is besluit op ' $n$ aksieprogram met twee dryf punte. Aan die een kant sou stappe van onderhandeling gevolg word waarin gepoog sou word om die gewraakte sinodebesluite "gewysig of ongedaan" te kry. Klem is daarop geplaas dat dit op 'n behoorlik kerkordelike manier gedoen moes word. Aan die ander kant sou begin word met voorbereidings vir 'n nuwe kerk onder Afrikaners waarin beswaarde lidmate ' $n$ gelukkige geestelike tuiste sou vind "sodat beswaardes gereed is as onderhandelings misluk" (Rapport 30 November 1986:1). 'n Finale besluit oor kerkstigting sou in Julie 1987 geneem word (Die Burger 29 November 1986: 2). Die vergadering het verder onder luide toejuiging besluit om by wyse van protes net ' $n$ nominale bydrae (byvoorbeeld ' $n$ rand elk) aan huidige eie gemeentes te doen en die res aan die Voortsettingskomitee te stuur. Die geld sou in 'n spaarrekening gehou word vir toekomstige besteding (Die Burger 29 November 1986:2). Hierdie gees van onversoenbaarheid sou ook die verdere optrede van die groep lidmate kenmerk. 'n Beswaarskrif wat onder die titel Geloof en Protes gepubliseer is, ${ }^{12}$ sou volg terwyl verdere gesprekke tussen die Voortsettingskomitee en die Algemene Sinodale Kommissie wat op 22 Junie 1987 plaasgevind het, ook op'n dooie punt uitgeloop het (Notule van die Algemene Sinodale Kommissie 22 Junie 1987:1).

Kerkstigting deur die beswaarde lidmate het 'n werklikheid geword. Op 27 Junie 1987 het 2500 mense ' $n$ vergadering in die Skilpadsaal bygewoon waar $80 \%$ van die teenwoordiges ten gunste van die stigting van'n nuwe kerk gestem het. 'n Groep van 70 het egter die saal verlaat en besluit om as beswaarde lidmate binne die Ned Geref. Kerk te bly en vandaar die gesprek voort te sit (Die Transvaler 29 Junie 1987:13).

Aan die begin van Oktober 1987 het die Algemene Sinodale Kommissie vir Ampsbediening en Evangelisasie van die Ned Geref. Kerk 'n opname gedoen om 'n aanduiding te kry van hoeveel lidmate die Ned Geref. Kerk verlaat het (Agenda van die Algemene Sinodale Kommissie van die Ned Geref. Kerk 23-24 November 1987:47). Uit die opname het dit geblyk dat 467 van die 1265 gemeentes van die Ned Geref. Kerk wel lidmate aan die nuwe kerk afgestaan het. Dit het 39,9\% van al die gemeentes verteenwoordig. Uit'n totaal van 7751 lidmate was daar 344 ouderlinge, 256 diakens en 19 diensdoende predikante wat teen 1 Oktober na die Afrikaanse Protestantse Kerk oorgegaan het. Die onderstaande tabel gee verdere toeligting:

11 Die Dagbestuur is verteenwoordig deur Proff JA Heyns, PB van der Watt, dr P Rossouw en ds. DJ Viljoen. Die beswaarde lidmate is verteenwoordig deur proff WJG Lubbe, A Swart, ds. CC Colyn en prof M Verster. (Agenda van die Algemene Sinodale Kommissie van die Ned Geref. Kerk, 18 - 19 Maart 1987: 8)

12 Die Kerkbode 8 Julie 1987:8 


\begin{tabular}{|c|c|c|c|c|c|c|c|c|c|}
\hline \multirow[b]{2}{*}{$\begin{array}{l}\text { NAAM } \\
\text { VAN } \\
\text { SINODE }\end{array}$} & \multirow[b]{2}{*}{$\begin{array}{l}\text { AANTAL } \\
\text { GEMEENTES } \\
\text { IN SINODE }\end{array}$} & \multirow[b]{2}{*}{$\begin{array}{l}\text { HOEVEEL } \\
\text { GEMEENTES } \\
\text { IN SINODE } \\
\text { HET } \\
\text { LIDMATE } \\
\text { AFGESTAAN }\end{array}$} & \multirow[b]{2}{*}{$\%$} & \multicolumn{6}{|c|}{$\begin{array}{l}\text { HOEVEEL HET DIE KERK VERLAAT T.G.V. } \\
\text { DIE APK }\end{array}$} \\
\hline & & & & 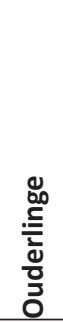 & $\frac{\check{c}}{\frac{n}{0}}$ & 离 & 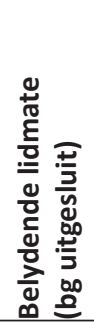 & 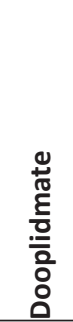 & do \\
\hline Wes-Kaap & 239 & 27 & 11.3 & 4 & 3 & 2 & 116 & 50 & 0.05 \\
\hline Oos-Kaap & 116 & 39 & 33.6 & 6 & 3 & 0 & 71 & 14 & 0.08 \\
\hline $\begin{array}{l}\text { Noord- } \\
\text { Kaap }\end{array}$ & 82 & 24 & 29.2 & 7 & 9 & 0 & 269 & 174 & 0.59 \\
\hline Natal & 69 & 31 & 44.9 & 11 & 13 & 0 & 203 & 95 & 0.48 \\
\hline O.V.S. & 173 & 99 & 57.2 & 64 & 35 & 4 & 932 & 388 & 0.69 \\
\hline Wes-Tvl & 150 & 89 & 59.3 & 92 & 76 & 5 & 1521 & 676 & 1.25 \\
\hline Noord-Tvl & 133 & 94 & 70.7 & 72 & 60 & 3 & 1442 & 119 & 0.86 \\
\hline Suid-Tvl & 136 & 64 & 46.3 & 21 & 7 & 3 & 370 & 79 & 0.26 \\
\hline S.W.A. & \multicolumn{9}{|c|}{ Blykbaar nog geen gemeentes van die APK gestig } \\
\hline $\begin{array}{l}\text { Midde- } \\
\text { Afrika }\end{array}$ & \multicolumn{9}{|c|}{ Blykbaar nog geen gemeentes van die APK gestig } \\
\hline Oos-Tvl & 90 & 41 & 45.6 & 67 & 50 & 3 & 729 & 440 & 0.96 \\
\hline TOTAAL & 1265 & 467 & & 344 & 256 & 19 & 5716 & 2035 & 0.44 \\
\hline
\end{tabular}

(Agenda van die Algemene Sinodale Kommissie van die Ned Geref. Kerk 23-24 November 1987:47).

Alhoewel die Ned Geref. Kerk net minder as 8000 lidmate verloor het, wat nie op 'n wesenlike kerkskeuring dui nie, het prof JA Heyns die gebeure raak saamgevat toe hy as volg reageer het: "Wie die Hoof van die Kerk liefhet, wie in die kerk gebore is en groot geword het, wie die kerk as geestelike moeder aanvaar en vir jare deur haar getrou en toegewyd met woord en sakramente gevoed is, kan nie anders as om te ween by die aanskoue van wat nou gebeur" (Die Kerkbode 22 Julie 1987:6).

\section{WAS DIE KOOL DIE SOUS WERD?}

As die aanvaarding van Kerk en Samelewing die Ned Geref. Kerk byna 8000 lidmate gekos het, moet die vraag gevra word of die kool die sous werd was? Was dit inderdaad die worsteling en die pyn van 'n kerkskeuring werd? 25 Jaar later vertel die geskiedenis dat dit inderdaad'n tydige koerswysiging was wat die kerk in 'n posisie gestel het om die reis oppad na 'n post-apartheid Suid Afrika mee te maak. Kerk en Samelewing het veral in die jare negentig van die vorige eeu belangrike deure vir die Ned Geref. Kerk oopgemaak.

\subsection{Die Rustenburg beraad 1990}

Die eerste deur wat deur Kerk en Samelewing oopgemaak is, was dié na die Rustenburgberaad. Die aanloop tot die beraad het reeds in 1989 begin toe die destydse staatspresident, FW de Klerk, na 'n wenk van prof JA Heyns tydens sy Kersboodskap 'n beroep op die kerke in 
die land gedoen het om 'n klimaat te help skep wat bevorderlik vir onderhandeling, versoening en verandering in die land sou wees (Du Toit ea. 2002:105). Die konferensie het vanaf 5-9 November 1990 by die Hunters Rest hotel buite Rustenburg plaasgevind (Du Toit 2002 105). Tydens hierdie konferensie, het prof WD Jonker die besluit van Kerk en Samelewing van 1986 wat in 1990 tydens die Algemene Sinode herbevestig is tot sy volle konsekwensie deurgetrek toe hy die volgende belydenis gedoen het: "I confess before you and before the Lord, not only my own sin and guilt, and my personal responsibility for the political, social, economic, and structural wrongs that have been done to many of you, and the results of which you and our whole country are still suffering from, but vicariously I dare also do that in the name of the DRC of which I am a member, and for the Afrikaner people as a whole. I have the liberty to do just that, because the DRC at its latest synod has declared apartheid a sin and confessed its own guilt of negligence in not warning against it and distancing it itself from it long ago" (Jonker 1998:204). In reaksie op Jonker se belydenis het Aartsbiskop Desmond Tutu opgestaan en gesê dat as die Ned Geref. Kerk vandag sê dat hy berou het, almal moet sê: "Ons vergewe julle." Jonker beskryf die toneel as volg: "Op daardie oomblik het almal opgestaan. Daar was trane, daar was'n gees van bewoënheid. So iets het ek nog nooit belewe nie. Ek het dit ervaar as 'n omarming, as 'n diepe gebaar van aanvaarding deur medegelowiges wat in diepe bewoënheid ons skuld van ons afneem" (Jonker 1998:205).

Hierdie belydenis van Jonker is die volgende dag deur prof Pieter Potgieter onderskryf toe hy gesê het: "The delegates of the DRC want to state unambiguously that we fully identify ourselves with the statements made by prof Jonker on the position of the church. He has in fact precisely reiterated the decision made by our General Synod in Bloemfontein recently. We want to see this decision of the synod as the bases of reconciliation with all people of all churches (Jonker 1998:207). Hierdie verklaring van Potgieter was'n bevestiging van die feit dat Kerk en Samelewing die Ned Gerf Kerk onherroeplik op'n nuwe koers geplaas het en in staat gestel het om sy rol in 'n nuwe demokraties Suid Afrika te vervul.

\subsection{Die Sinode van versoening 1994}

'n Tweede belangrike deur was dié na versoening tydens die Algemene Sinode van 1994. ' $n$ Belangrike gebeurtenis het tydens die negende vergadering van die Algemene Sinode van Ned Gerf Kerk in 1994 plaasgevind toe mnr Nelson Mandela, nuutverkose president van Suid Afrika, die sinode op 13 Oktober 1994 toegespreek het (Handelinge 1994: 536). Die Sinode was die eerste wat na afloop van die eerste veelrassige verkiesing op 27 April 1994 in 'n nuwe demokratiese Suid Afrika plaasgevind het (Du Toit ea. 2002:110).

In sy toespraak het mnr Mandela verwys na apartheid as ' $n$ verskroeide aarde beleid wat verkeerd en sondig was. Hy het verder verwys na die lang stryd in die NGK rondom apartheid en die diepe sielsworsteling wat baie lidmate van die kerk deurgegaan het. Mandela het ook erkenning gegee aan Kerk en Samelewing as'n belangrike mylpaal maar die sinode ook uitgedaag om erkenning te gee aan persone soos Dr Beyers Naude en dr Ben Marais wat die kerk teen apartheid en rassisme gewaarsku het (Handelinge 1994:537). Hierdie toespraak het die wiel aan die rol gesit vir 'n versoeningsproses wat die sinode as die Sinode van Versoening bekend sou laat word. Op 19 Oktober het die vergadering die volgende besluit goedgekeur: "In die lig van die klag van politieke dienstigheid deur die NGK wys die Algemene Sinode lidmate daarop dat daar deur die jare heen steeds lidmate, ampsdraers en selfs kerklike vergaderinge was wat ' $n$ duidelike profetiese stem laat hoor het. Die Algemene Sinode erken met spyt dat daar in die verlede dikwels van kerklike kant op 'n onbarmhartige en onsmaaklike wyse teenoor sulke persone gehandel is (Handelinge 1994:501). In die daaropvolgende dae van die vergaderings is dr Beyers Naude en prof Ben Marais in die vergadering omverskoning gevra. Die sinode het nie 
net gepraat nie, maar ook gedoen (Du Toit ea. 2002:116). Kerk en Samelewing het die deure van die Ned Geref. Kerk vir mnr Nelson Mandela oopgemaak en die kerk in staat gestel om 'n pad van versoening te loop, nie net met die nuwe president nie, maar ook met profete uit eie geledere.

\subsection{Deelname aan die Waarheids- en Versoeningskommissie: 1997}

'n Derde belangrike deur was dié na die Waarheids- en Versoeningskommissie. Mnr Nelson Mandela het in sy toespraak voor die Algemene Sinode verwys na ' $n$ forum van heling wat bekend sou word as die Waarheids - en Versoeningskommissie (WVK) ( Handelinge 1994:537). Die vraag wat gou aan die orde was, was: "moes die Ned Geref. Kerk voor die WVK getuig of nie?" (Du Toit ea. 2002:119). Die aanvanklike besluit van die Algemene Sinodale Kommissie van die Ned Geref. Kerk was om nie'n voorlegging voor die WVK te doen nie ${ }^{13}$. Ds. Freek Swanepoel, voorsitter van die Algemene Sinodale Kommissie van die Ned Geref. Kerk het na afloop van die vergadering tydens'n perskonferensie gesê dat die besluit egter ter enige tyd verander kon word. Alhoewel die vergadering amptelik besluit het om nie'n voorlegging te doen nie, was Swanepoel self van mening dat die Ned Geref. Kerk dit aan sy lidmate verskuldig was om sy verhaal oor die landsgebeure op skrif te stel. Hy het vier maande later gesê: "om nou te swyg sou dwaas wees." (Beeld 14 Februarie 1997:4). Op 22 Mei 1997 het die Algemene Sinodale Kommissie sy standpunt om nie 'n voorlegging aan die WVK te doen nie, herbevestig. Dit het gevolg op 'n brief waarin die Ned Geref. Kerk saam met ander kerke gevra is, om dit wel te doen (Du Toit 2002:120). Daar is wel besluit om die verhaal van die Ned Geref. Kerk met betrekking tot volkere en rasseverhoudinge in Suid Afrika, soos wat dit sedert die totstandkoming van die Algemene Sinode in 1962 ontwikkel het, op skrif te stel ${ }^{14}$. Prof PJG Meiring, enigste verteenwoordiger van Die Ned Geref. Kerk op die WVK wou egter nie aanvaar dat die kerk nie 'n voorlegging sou maak nie. In herhaalde briewe aan die skriba van die Algemene Sinodale Kommissie het hy die Ned Geref. Kerk versoek om tog 'n voorlegging te maak (Meiring 1997:5). Die pogings van prof Meiring het vrugte afgewerp toe die Algemene Sinodale Kommissie tydens ' $n$ vergadering van 28 -30 Oktober 1997 die volgende besluit geneem het: "die voorsitter moet die NGK by die getuienisgeleentheid verteenwoordig en hy word versoek om, indien hy'n spreekbeurt kry, klem te lê op die kerk se versoeningstaak en die toekoms. Daar sal egter nie'n formele voorlegging deur die NGK gemaak word nie" (Notule Algemene Sinodale Kommissie 28 Oktober 1997:3). Op 19 November 1997 het ds. Freek Swanepoel die Ned Geref. Kerk in Port Elizabeth verteenwoordig tydens 'n openbare getuienisgeleentheid vir die meer evangeliese en Afrikaanse kerke. In sy toespraak het ds. Swanepoel onder meer gesê dat die Ned Geref. Kerk verbind is tot versoening, dat die Ned Geref. Kerk dit saam met ander wil aanpak, wat onder die praktiese implikasies van versoening verstaan word en dat versoening persoonlike kontak vereis. Hy het ten slotte verwys na die verlede en die toekoms (Meiring 1999:286). Met die getuienis van ds. Swanepoel voor die WVK kon die Ned Geref. Kerk weer sy regmatige plek in die galery van kerke in Suid Afrika inneem. Dit is moontlik genaak deur die waterskeidende besluite van Kerk en Samelewing.

\subsection{Hertoelating tot die Wêreldbond van Gereformeerde Kerke: 1998}

'n Vierde belangrike deur was dié na die Ned Geref. Kerk se hertoelating tot die Wêreldbond van Gereformeerde Kerke (WBGK). Die Ned Geref. Kerk se ondersteuning van en Bybelse fundering

13 In 'n brief aan die Voorsitter van die Waarheids- en Versoeningskommissie gedateer 27 .08.1997 het die Skriba van die Algemene Sinodale Kommissie die WVK in kennis gestel dat die Ned Geref. Kerk nie ' $n$ voorlegging aan die WVK sou doen nie maar dat Reis met Apartheid aan alle belangstellendes beskikbaar was..

14 Hierdie dokument is deur dr FM Gaum saamgestel. Dit is in Augustus 1997 gepubliseer met die titel: Die verhaal van die NG kerk se reis met apartheid(1960 -1994) - 'n getuienis en 'n belydenis. 
van apartheid was direk daarvoor verantwoordelik vir die skorsing van die kerk tydens die WBGK se vergadering in Ottawa in $1982^{15}$ Die aanvaarding van Kerk en Samelewing in 1986 was die eerste tree na die opheffing van die skorsing. Na 'n ontmoeting tussen ' $n$ afvaardiging van die WBGK en die Dagbestuur van die Algemene Sinodale Kommissie in Bloemfontein in April 1997, is die Ned Geref. Kerk genooi om die $23^{\text {ste }}$ vergadering van die WBGK wat in Augustus 1997 in Debrecen Hongarye plaasgevind het, as waarnemer by te woon (Du Toit 2002:238). Die Uitvoerende komitee van die WBGK het intussen voorgestel dat indien beide die Algemene Vergadering van die WBGK in 1997 en die Algemene Sinode van die Ned Geref. Kerk in 1998 'n mosie aanvaar wat deur die Uitvoerende komitee voorberei is, die skorsing van die Ned Geref. Kerk onmiddellik beëindig sou word. In hierdie mosie is bevestig dat enige teologiese regverdiging van apartheid ' $n$ status confessionis daarstel en ' $n$ weerspreking van die evangelie is. Van die Algemene Sinode is verwag om apartheid binne hierdie raamwerk as verkeerd en sondig te verwerp, "not only in its effects and operations, but also in its fundamental nature" (Agenda 1998:41). M Opocensky, Sekretaris-Generaal van die WBGK het ' $n$ begeleidende brief aan die Algemene Sinode gestuur waarin die besluit verder toegelig is terwyl hy self ook tydens die vergadering teenwoordig was. Na ontvangs van die brief en Opocensky se toeligting het die Algemene Sinode die "resolution" sonder enige wysiging aanvaar (Handelinge 1998:413). Dit het beteken dat die skorsing van die Ned Geref. Kerk weens sy verdediging van apartheid na sestien jaar opgehef is. Strauss is korrek wanneer hy skryf: "Die verbreking van die isolasie van die NG Kerk wat in 1986 begin het, was nou voltooi" (Du Toit 2002:240).

\section{KONKLUSIE}

25 jaar na die aanvaarding van Kerk en Samelewing tydens die Algemene Sinode van 1986, is dit duidelik dat die dokument en die beleid wat daarin vervat is, 'n waterskeiding vir die Ned Geref. Kerk was. Die storms wat daardeur ontketen is, moes verduur word, omdat dit verskeie deure vir die Ned Geref. Kerk oopgemaak het sodat die kerk in die negentigerjare weer sy regmatige plek tussen die kerke, nie net in Suid Afrika nie, maar in die wêreld kon inneem. Die wins wat saam met Kerk en Samelewing gekom het, was groter as die verlies. Die era van Kerk en Samelewing het tot ' $n$ einde gekom tydens die Algemene Sinode van 1994 toe besluit is besluit dat Kerk en Samelewing se tyd uitgedien was. Die vergadering het dit soos volg verwoord: "Die Algemene Sinode beskou Kerk en Samelewing nie as 'n dokument wat telkens hersien moet word nie Die kerk leef nou in 'n nuwe situasie waarin dringende makro - sosiaal-etiese probleme ons aandag verg" (Handelinge 1994:578). Met hierdie besluit was die tyd van Kerk en Samelewing verby. Vyf en twintig jaar later onderstreep die geskiedenis egter die belangrike rol wat Kerk en Samelewing in die Ned Geref Kerk gespeel het. Dit het die kerk gehelp om die Albatros van apartheid van sy nek af te gooi en 'n nuwe koers in te slaan. 'n Groot deur na nuwe uitdagings in 'n nuwe millennium is vir die Ned Geref. Kerk oopgemaak. Kerkhereniging in die familie van Ned Geref Kerke sou die grootste uitdaging word.

\section{BIBLIOGRAFIE}

Boesak, AA 1984. Black and Reformed: Apartheid, Liberation and the Calvinist Tradition. Black Theology Series no 2. Braamfontein: Skotaville Publishers.

Bosch, DJ; König, A en Nicol, WD (reds) 1982. Perpektief op die Ope Brief. Kaapstad: Human \& Rousseau.

De Gruchy, JW 2004. The Church Struggle in South Africa. London: SCM press.

Du Toit, PR ea. 2002. Moeisame pad na hernuwing: Die NGK se pad van isolasie en die soeke na nuwe relevansie 1974 -2002. Bloemfontein: Barnabas.

15 Vergelyk 2.4 van hierdie artikel. 
Geldenhuys, O’ Brein FE 1982. In die Stroomversnellings. Kaapstad: Tafelberg - Uitgewers Beperk. Jonker, WD 1998. Selfs die Kerk kan verander. Kaapstad: Tafelberg - Uitgewers Beperk.

Meiring, Piet 1999. Kroniek van die waarheidskommissie. Vanderbijlpark: Carpe Diem.

Van der Merwe, JM 1990. "Ras, Volk en Nasie"en "Kerk en Samelewing" as beleidstukke van die Ned Geref. Kerk - 'n Kerkhistoriese studie. Ongepubliseerde DD proefskrif. Universiteit van Pretoria.

\section{Kerklike Dokumente:}

Agenda van die Algemene Sinodale Kommissie: 23 -24 November 1987.

Agenda van die Algemene Sinode van die Ned Geref. Kerk: 1998.

Agenda van die Breë Moderatuur van die Algemene Sinode van die Ned Geref. Kerk: 1979.

Handelinge van die Algemene Sinode van die Ned Geref. Kerk: 1978.

Handelinge van die Algemene Sinode van die Ned Geref. Kerk: 1982.

Handelinge van die Algemene Sinode van die Ned Geref. Kerk: 1986.

Handelinge van die Algemene Sinode van die Ned Geref. Kerk: 1994.

Handelinge van die Algemene Sinode van die Ned Geref. Kerk: 1998.

Kerk en Samelewing: 'n Getuienis van die Ned Geref Kerk. 1986. Bloemfontein: NG Sendingpers.

Notule van die Algemene Sinodale Kommissie: 22 Junie 1987.

Notule van die Algemene Sinodale Kommissie: 28 Oktober 1997.

Proceedings of the 21st General Council of the World Alliance of Reformed Churches, Ottawa: 1982.

Ras, Volk en Nasie en Volkereverhoudinge in die lig van die Skrif. 1974. Pretoria: N.G.Kerk-Uitgewers.

Sakelys van die Algemene Sinodale Kommissie: 28 - 30 Oktober 1997

\section{Referate:}

Gerber, JJ Voordrag gelewer tydens Teologiese dag. Universiteit van Pretoria. 9 Februarie 2011

\section{Kerklike tydskrifte en Koerante}

Die Kerkbode 1980. 5 November 1980, p1.

Die Kerkbode 1982. 9 Junie 1982, p1.

Die Kerkbode 1982. 23 Junie 1982, p5.

Die Kerkbode 1982. 25 Augustus 1982, p3.

Die Burger 1982. 27 Augustus 1982, p1.

Die Kerkbode 1982. 1 September 1982, p1.

Die Burger 1986. 22 Oktober 1986, p1.

Die Vaderland 1986. 20 Oktober 1986, p1.

Die Afrikaner 1986. 29 Oktober 1986, p1.

The Citizen 1986. 3 November 1986, p2.

Die Burger 1986. 3 November 1986, p2.

Die Vaderland 1986. 11 November 1986, p4.

Beeld 1986. 27 November 1986, p6.

Rapport 1986. 30 November 1986, p1.

Die Burger 1986. 29 November 1986, p2.

Die Transvaler 1987. 29 Junie 1987, p13.

Die Kerkbode 1987. 22 Julie 1987, p6.

Beeld 1997. 14 Februarie 1997, p4.

\section{TREFWOORDE}

Kerk en Samelewing

Apartheid

Algemene Sinode van die Ned Geref Kerk

Versoening

Belydenis
KONTAKBESONDERHEDE

Dr JM van der Merwe

Fakulteit Teologie

Universiteit van Pretoria

0002 PRETORIA

E-posadres: johan.vdmerwe@up.ac.za

Sel: 0825653768 